\title{
Closing the Racial Wealth Gap: Establishing and Sustaining an Initiative
}

\author{
Kilolo Kijakazi ${ }^{1}$
}

Published online: 15 February 2016

(c) The Author(s) 2016. This article is published with open access at Springerlink.com

\begin{abstract}
By 2003, the savings and asset building field had achieved critical research and policy successes. However, some challenges it faced were the lack of a substantial presence of organizations of color in the field and the absence of experts of color at decision-making tables. Over the course of 11 years, a strategy was developed within the Ford Foundation to gain an understanding of the knowledge and perspective of communities of color about saving and wealth building and to then include this perspective within the asset building field. This article provides a social history of the work undertaken to create and sustain this initiative.
\end{abstract}

Keywords Racial wealth gap - Wealth gap - Saving and asset building · Financial security · Economic security · Children's savings accounts · Social security

\section{Early Successes and Challenges for the Saving and Asset Building Field}

In 2003, I became a program officer at the Ford Foundation and took responsibility for the portfolio on saving and asset building. At that time, a critical component of the portfolio, the American Dream Demonstration and Evaluation (ADD) was just concluding. ADD was the first empirical

Kilolo Kijakazi

kkijakaz@urban.org

1 Urban Institute, 2100 M St., NW, Washington, DC 20037, USA study of the impact of individual development accounts (IDAs) which are matched savings accounts for low-income families. IDAs were designed to test the theory espoused by Michael Sherraden in his seminal book Asset and the Poor: A New American Welfare Policy (1991). He asserted that when low-income families are provided with the kinds of structures and incentives for saving to which higher-income families already had access (e.g., through employer-sponsored retirement plans), they too will save and invested in long-term assets. The ADD results showed that IDA participants did save and invest in homes, higher education, and retirement savings (Mills et al. 2004; Schreiner et al. 2002).

In addition to research, the portfolio also had been supporting advocacy at the national level. National policy organizations such as CFED and the New America Foundation translated research findings for members of Congress and advocated for policy change that would create the structures and incentives for low-income families to save and accumulate assets. In 1998, Congress enacted the Assets for Independence Act, a national demonstration program that provided $\$ 125$ million over 5 years to be used as matching funds for IDA programs established by community-based organizations.

These research and policy outcomes were critical successes. However, there also were challenges that remained. One challenge was the lack of a substantial presence of organizations of color in the growing savings and asset building field. In addition, there was an absence of people of color with expertise in this field at decisionmaking tables. Upon assuming the portfolio, it was important to gain an understanding of the knowledge and perspective of communities of color about saving and wealth building and to then include this perspective in the asset building field. 


\section{Developing an Understanding of the Perspective of Communities of Color}

To develop a better understanding of the perspective of communities of color on saving and asset accumulation, Ford engaged the Insight Center for Community and Economic Development (formerly the National Economic Development and Law Center) to be a managing partner in assembling a body of knowledge and building an awareness in the field about this point of view.

\section{Focus Groups}

As a first step, Ford asked Insight to conduct a series of focus groups with different communities of color. Separate groups were held for: (1) African Americans; (2) immigrants from the Caribbean and African nations; (3) Latinos; (4) Latino immigrants; (5) Asian Americans and Pacific Islanders; (6) immigrants from Asian American and Pacific Island nations; (7) Native Americans living on a reservation; and (8) Native Americans living in an urban area.

The focus groups found that many individuals banked or had previously banked in financial institutions. For some, however, requirements for minimum balances and monthly service charges were prohibitive. Others withdrew from financial institutions when they experienced unanticipated fees and penalties as their often volatile incomes resulted in balances below the minimum requirement or insufficient funds in their accounts.

An important finding was that participants from each of the focus groups reported saving outside of financial institutions. Of particular interest was the collective approach to savings that participants from each community of color discussed. These savings circles are known by various names including the general name Rotating Savings and Credit Associations or ROSCAs. In these savings circles, each participant contributes a designated amount on a regular basis and each member of the circle gets a turn at receiving all of the contributions in a lump sum. This common approach to savings across communities of color heightened our interest in knowing more about the way in which people of color think about saving and wealth and how they approach saving.

\section{Experts of Color on Saving, Wealth, and Financial Security}

To deepen our understanding of the perspective of people of color, we also wanted to obtain the views of people of color with expertise in the asset building field. However, there were rarely experts of color at the decision-making tables on saving and asset building with whom we could engage.
With the assistance of Insight, we identified an initial group of experts of color and invited them to attend a convening at Tuskegee University in the spring of 2004. The goal was to discuss the perspectives of different communities of color about saving and wealth. This group of 17 people included African Americans, Latinos, Native Americans, Native Hawaiians, Asian Americans and Pacific Islanders. Participants held discussions as a whole and by racial and ethnic groups. What resulted was a description of wealth that was shared across racial and ethnic groups. They defined wealth as being more than what an individual is able to accumulate. Instead, wealth is measured in terms of the well-being of the family, extended family, or in some cases, the community. The individual is not perceived as wealthy if his or her family is not wealthy. And similar to the focus groups discussed above, the experts of color also discussed the collective approaches to savings in which many communities of color engage.

The participants in this meeting determined that it would be important to meet again and they identified other researchers, policy analysts, practitioners, academicians, and business people of color with expertise in saving, asset building, and financial security who should be invited to the next meeting. We reconvened at Tuskegee in 2005 with over 50 participants who presented their work on panels. The panels were followed by in-depth discussions about their work and common challenges. The discussions groups combined people of different races and ethnicities, different disciplines, and different skills sets.

In 2006, Melvin Oliver, the former vice president of Ford Foundation who established its Asset Building and Community Resources Program, invited the group to convene at the University of California, Santa Barbara, where he is the Dean of Social Sciences. Oliver, along with Thomas Shapiro, co-authored the award winning book Black Wealth/White Wealth: A New Perspective on Racial Inequality (1997). This landmark book shed light on the extent to which the difference in wealth between white Americans and African Americans-the racial wealth gap-far exceeds the difference in income between the two groups. Moreover, the book documents policies that created the racial wealth gap and led to the "sedimentation of inequality." During the convening at Santa Barbara, participants presented their research on issues of asset building that were central to communities of color. By the end of the meeting, they concluded that closing the racial wealth gap would be the focus of their work going forward.

Until this time, the convenings had been private meetings, primarily with experts of color. This seclusion was critical during the period when the participants were examining the perspectives of their communities, exploring the impact of the larger environment on their communities, 
solidifying as a group, and choosing a focus for their work. In addition to the annual meetings, Ford provided funding to Insight to create a listserv that would allow the group to remain connected between convenings, and to share information about research, policy, and practice regarding saving, asset building, and the racial wealth gap. And Insight was funded to create a sub-grant program that would support the work that these experts of color were undertaking. Twenty-six applications were submitted, and six sub-grants were awarded.

A decision also was made to hold the next convening at the Ford Foundation in 2007. The intent was to build a collaborative approach to solving the problem of the racial wealth gap across the saving and asset building field. Invitations went out to all of the grantees in the saving and asset building portfolio, Ford staff, and representatives of other foundations working on saving and asset building. Insight contracted with Washington Koen Productions to create a video on the formation of what became known as the Experts of Color Network (ECON) and the issue of the racial wealth gap development, through interviews with several members. The convening opened with the video, $A$ Path to the Future: Closing the Racial Wealth Gap (Washington and Koen 2007). A plenary session followed that examined why closing the racial wealth gap is imperative for the economic health of the nation and the strategies that can be used to achieve greater diversity and inclusion in the asset building field. Participants engaged in workshops to better understand the relationship between the racial wealth gap and homeownership, savings for higher education, employment, entrepreneurship, financial services and products, and land ownership. In addition to grantees, the event was attended by Ford leadership, as well as program officers from Ford and other foundations.

Subsequent convenings were held primarily in Washington, DC, on Capitol Hill to inform policymakers about the racial wealth gap and underscore the need for policy change to eliminate it. Of note was the 2009 convening, "The Color of Wealth," held shortly after President Obama took office. The enormous excitement about the first African-American President dove-tailed with the excitement ECON was generating about the issue of closing the racial wealth gap. Insight released the report Laying the Foundation for National Prosperity: The Imperative of Closing the Racial Wealth Gap (Lui 2009). This report described the significance and root causes of the problem and offered solutions. On the first morning of the convening, the Washington Post editorial addressed the racial wealth gap and announced that the convening would be taking place. The convening room was filled to capacity and included the majority of the 140 ECON members. Many members of Congress attended and served as keynote speakers and panelists, along with ECON members. Participants included the House Majority Leader, the leadership and membership of the Democratic Caucus, Congressional Black Caucus, Congressional Hispanic Caucus, and Congressional Asian Pacific Islander Caucus, and others. Keynote remarks also were provided by White House staff who asked ECON to keep them informed of ideas on what could be done to address the racial wealth gap. On the first evening of the convening, CNN carried a story on the racial wealth gap and interviewed the Insight project director. Stories also appeared on NPR, Reuters, Fox Business News, C-SPAN, Huffington Post, TheRoot.com, and the San Francisco Chronicle.

The racial wealth gap had been brought to the attention of the national media and the federal government. Subsequently, Insight was able to secure meetings at the White House for ECON members, including a meeting with the chief of staff in 2011.

\section{Developing a Theory of Change and Strategy}

The knowledge gained from conducting focus groups and from the development of ECON helped refine the theory of change and grantmaking strategy for the portfolio. The key provisions of the theory of change were as follows:

- In combination with income security, saving over a lifetime is an effective way to accumulate financial assets and reduce poverty;

- Public policy that is inclusive of low-income people and people of color is the best vehicle for assisting families and individuals to save, build assets, and reduce debt;

- Research, innovative practice, and policy analysis are fundamental building blocks for designing effective policy;

- Given that low-income and low-wealth families are disproportionately people of color, the field's researchers, policy experts, and practitioners must reflect the composition of this population. They must participate in:

- Designing, developing, and implementing research;

- Determining what policy analyses to undertake; and

- Making decisions about the design, implementation, and administration of the programs.

- Problems are best solved when people who live and work closest to them are engaged in developing the solutions and

- For a program or policy to reach scale, it must be considered relevant and effective by the people it is intended to serve, or they will not participate. 


\section{The Broader Work of the Portfolio}

The portfolio continued to cover a wide body of work including research and policy analysis on the overall wealth gap between low-income and higher-income families. However, a focus on the racial wealth gap also was incorporated into the work.

As part of the broader work, Ford was a principal funder, along with a collaboration of other foundations, that supported a national demonstration and evaluation of children's savings accounts (CSAs) called SEED—Saving for Education, Entrepreneurship, and Downpayment. Like IDAs, the concept of CSAs was based on Michael Sherraden's theory. These savings accounts, ideally, would be established for all children at birth using public dollars for the initial deposit. Babies born into low-income families would receive a larger deposit and any additional funds contributed to these accounts by families and friends would receive matching public funds. There would be no access to the publically funded portion of an account until the child turned 18. At that point, funds could be used for higher education, to purchase a home, to start a business, for retirement savings, or for other wealth-building purposes. (Some CSA designs allow for unrestricted use of the funds at age 18.) Grantees collaborating on the SEED project included CFED, the Center for Social Development, New America Foundation, the University of Kansas, and RTI International-which conducted the evaluation.

Unlike ADD, the SEED study included a centrally administered program, rather than just community-based programs. The Oklahoma state treasurer's office implemented the SEED program for approximately 1000 newborns using the 529 college savings plan. The evaluation found that a universal CSA can be successfully implemented and SEED increased the share of families with a 529 account by 15 percentage points (Marks et al. 2014). Further research by CSD also indicates positive psychosocial impacts of SEED (Beverly et al. 2015).

Retirement security also was supported by the portfolio. Social Security is the largest financial asset that low- and moderate-income families have. This social insurance program not only provides income for workers upon retirement, it also provides income for the worker if he or she becomes disabled. And Social Security provides benefits to the dependents of workers if the worker dies, becomes disabled, or retires. Social Security is the kind of long-term asset that helps families weather economic and health-related shocks and prevents many families and people of all ages from sliding into poverty.

CSAs and the Social Security program have a progressive benefit design. The larger initial deposit and the matching dollars contributed to CSAs held by children in low-income families give their accounts an extra boost to compensate for their families having fewer resources to contribute to their accounts. Similarly, Social Security benefits are designed to provide low-wage workers with a higher percentage of their pre-retirement earnings than high-wage workers receive. These progressive designs help to reduce the wealth gap, and they also help to decrease the racial wealth gap.

\section{Weaving the Perspective of Communities of Color Throughout the Portfolio}

The work of engaging experts of color in the asset building field and addressing the racial wealth gap was woven throughout the portfolio. Efforts to address racial and ethnic aspects of the saving and asset building work were not stand-alone components. The work on the racial wealth gap was sustainable because it was designed to be integral to the rest of the portfolio. Multiple approaches were used to accomplish this objective.

\section{Indirect and Direct Support for Experts and Organizations of Color}

With respect to the overall portfolio, Ford emphasized the importance of grantees having diverse professional staffs and boards. These were key criteria for reviewing and selecting proposals. Grantmaking for this portfolio paid particular attention to these criteria and worked with grantees to achieve or make substantial progress toward the objective of having diverse and inclusive organizations.

Grants also were made to organizations representing people of color, to engage or expand their work in research and policy analysis on saving and asset building. The early grants included the Center for a New Economy, First Nations Development Institute, the National Council of La Raza, the Joint Center for Political and Economic Studies, the Center for Family Policy and Practice, Ifetayo Cultural Arts Academy, and the University of California, Los Angeles (UCLA) Asian American Studies Center.

The early grantmaking that addressed retirement security also included support to organizations representing people of color to produce research, conduct policy analyses, and engage in advocacy. Among these organizations were the UCLA Center for Policy Research on Aging (that focused on the Latino population); the National Council of Negro Women; Global Policy Solutions; and the NAACP. ${ }^{1}$

\footnotetext{
${ }^{1}$ Other grantees addressing this work included the National Academy of Social Insurance, the Center on Budget and Policy Priorities, Urban Institute, the Institute for Women's Policy Research, the Center for Retirement Research at Boston College, the Peterson Institute for International Economics, the Pension Rights Center, Aspen, IFS, and the Employee Benefit Research Institute.
} 
After the initial grantmaking on Social Security, funding was provided to the National Academy of Social Insurance (NASI), which served as a managing partner on retirement security, to conduct education at the national level and to put in place a sub-granting program to organizations that had national chapters or the ability to reach beyond the Washington, DC beltway. One such grant was made to the Center for Global Policy Solutions and Insight. These organizations established the Commission to Modernize Social Security comprised of leaders of color with expertise on retirement security-several were ECON members. They produced the report A Plan for a New Future: The Impact of Social Security Reform on Communities of Color (2011). This report described the importance of the Social Security program to people of color and the need to ensure the adequacy of coverage and benefits, in addition to restoring the solvency of the program. The report provided a set of recommended reforms that could achieve both objectives. These reforms were championed by Congresswoman Gwen Moore and introduced in the House of Representatives, most recently, as The Social Security Enhancement and Protection Act of 2015 (H.R. 1756).

\section{Supporting a Pipeline of New Experts of Color}

To sustain the objective of having experts of color who contribute their knowledge and experience to the field of saving and asset building, it was necessary to support a pipeline of new scholars. A pipeline was developed to reach students from the undergraduate through post-doctoral levels. This was achieved through grantmaking to organizations with internship or fellowship programs and to colleges and universities, including Historically Black Colleges and Universities (HBCUs).

The Urban Institute (Urban) received support for the creation of the Academy for Public Policy Analysis and Research, a nine-week internship program for college undergraduates during the summer between their junior and senior years. The interns received classroom training on research design, major data bases, statistical analysis, and social policy issues (Rawlings and Williams 2012). Instruction was provided by researchers at Urban and from other think tanks and Universities in the DC area. In addition, the students took a field trip once a week to key policy institutions and were addressed, for example, by officials from the Office of Management and Budget and the senior advisor to the Speaker of the House of Representatives. Each intern completed a guided research project during the summer program and presented it at a convening held by Urban at the end of the summer. They also received career skills development counseling. The Academy's support for interns continued for a year with mentoring, presentations by the interns at a national professional research conference, counseling on jobs and graduate schools, and support preparing research papers for publications.

There were no program dropouts. Of the 41 students who completed the Academy, six are currently enrolled at prestigious (and fully funded) $\mathrm{PhD}$ programs at U.C. Berkeley, the University of Michigan, Harvard University, NYU's Robert F. Wagner Graduate School of Public Service, and Brown University. Among these doctoral students are a Ford Foundation Dissertation Fellow and a National Science Foundation grantee. An additional, twelve program alumni have completed or are enrolled in Masters degree programs and three are enrolled in, or have completed, law school. Five are in Teach for America. Others are working or have worked at National Opinion Research Council, The Urban Institute, American Institutes for Research, National Congress of American Indians, Latino Economic Development Center, the Domestic Policy Council, US Department of Housing and Urban Development, US Department of Education, the City of Baltimore, and the California Department of Public Health-among other distinguished institutions.

NASI received funding to provide education to policymakers, the media, and the general public about the importance of Social Security as a financial asset for lowincome families. As part of its work, NASI conducted a summer internship program every year. While not targeted to students of color, over time, the students selected were increasingly diverse. One of the events in which these interns engaged was the Summer Academy on Social Insurance. This one-day seminar on Social Security was open to all summer interns in Washington, DC, and regularly drew at least 100 racially and ethnically diverse participants who were interested in public policy. NASI's interns framed and led the discussions on Social Security policy options for restoring solvency for the program and ensuring the adequacy of benefits.

Support was provided to Howard University's Economics Department to create the Center on Race and Wealth (Center). Howard is an HBCU. The Center was staffed by professors whose course work and research addressed saving and asset building issues, and graduate students who gained experience by participating in the Center's research. In addition, the Center held a two-week, summer internship program for undergraduate and graduate students. Student received one-on-one support from Center scholars in polishing the research papers that they submitted as part of the internship application process. Scholars assisted students in developing their papers into publishable documents. In addition, the interns participated in seminars where they received instruction on translating research into policy documents that could be shared with policymakers. And interns attended forums with 
representatives of policy organizations and communitybased organizations where strategies were developed for conveying community concerns about financial security and asset building to policymakers.

Tuskegee University, another HBCU that is located in Alabama near the Gulf Coast, received funding following Hurricanes Katrina and Rita. The purpose of the grant was to assist communities in the Deep South, especially those in hurricane-struck areas, to use asset building as a strategy for disaster recovery and a means of reducing poverty and land loss. Tuskegee created a coalition of organizations from Alabama, Mississippi, Louisiana, and Florida to undertake this work. As part of this effort, Tuskegee engaged it graduates students in developing a website for the coalition to facilitate communication with coalition members and inform the public about the work of the coalition.

The CSD at Washington University was a long-standing grantee within the portfolio. CSD is exceptional for its diversity and inclusion of graduate students of color from the US and abroad in the research undertaken at the center. Doctoral students of color who have been engaged in research at CSD have gone on to become professors (many tenured) at top universities across the country. They continue to conduct research and publish, and in at least one instance, to create a new university-based research center address savings and asset building - the Center on Assets, Education, and Inclusion founded by William Elliott.

The University of Michigan began receiving funding from Ford in 1989 for its Research and Training Program on Poverty and Public Policy for post-doctoral fellows and doctoral students from communities of color and/or from economically disadvantaged backgrounds who are underrepresented in the national poverty research community. Fellows received financial support for 2 years to undertake research in this social science training program that integrated research and training activities and implemented a multi-disciplinary approach to the study of poverty. Over the course of the program, they studied a wide range of social science theories and methodological techniques in the classroom, served as apprentice researchers under the supervision of nationally recognized scholars, designed and conducted their own research projects, and had access to the all of resources and research support services of the University. This support was continued under the saving and asset building portfolio with an emphasis on recruiting fellows who had an interest in issues related to asset building, such as IDAs, CSAs, pensions, and Social Security reform. About 40 fellows completed the program since its inception. Many become tenured professors in top universities across the country, researchers at think tanks, and government administrators. One fellow who held a senior executive service position at a federal agency served as an advisor to the Urban Institute's Academy.

\section{The Evolution of the Portfolio into the Building Economic Security Over a Lifetime Initiative}

In 2007, the leadership of the Ford Foundation changed and the organization undertook a strategic planning process including the review of each portfolio. Fortunately, a midterm assessment of the portfolio was already being conducted by Stillwater Consulting, and the results of the study were able to feed into the strategic plan.

The mid-term assessment found that while the primarily national focus of the work on research and advocacy had been impactful, achieving universal public policies to support saving and asset accumulation by low-income households would require two additional approaches. It would be necessary to build a constituency that educated the media and public, and advocated to their policymakers about the importance of such policy change. And it would be important to create a policy communications infrastructure that would allow advocates from the grassroots to the national level to communicate. To accomplish this, the Building Economic Security Over a Lifetime (BESOL) initiative was formed. This initiative maintained the national research and policy activities of the saving and asset building portfolio, and added state and regional coalition building and a communications infrastructure.

\section{Expanding the Strategy to Include Local and State Coalitions}

The portfolio had previously funded a few local and statewide work. EARN, a San Francisco-based nonprofit, operated one of the nation's largest IDA programs. Heartland Alliance for Human Needs and Human Rights, along with the Sargent Shriver National Center on Poverty Law, organized and coordinated the Illinois Asset Building Group (IABG). And First Nations Development Institute, a national Native American policy, research and funding organization helped to establish the first statewide asset building coalition in Oklahoma-the Oklahoma Native Assets Coalition (ONAC).

Under BESOL, support was expanded for these organizations so that they could build statewide coalitions with strong grassroots constituencies. First Nations Development Institute continued its partnership with ONAC and also engaged the Oklahoma Policy Institute to form the Oklahoma Asset Network (formerly the Oklahoma Asset Building Coalition), reaching both Native American and non-Native American communities. In addition, BESOL 
funded the Texas-based organization, Center for Public Policy Priorities, and its partner, RAISE Texas. Finally, the coalition that was originally established by Tuskegee University was substantially expanded with the help of Realize Consulting. The Alabama Assets Coalition, the Coalition for a Prosperous Mississippi, the Louisiana Building Economic Security Together (LABEST), and Florida-based War on Poverty formed the Southern Regional Asset Building Coalition (SRABC). Each of the SRABC partner organizations developed its own statewide coalition, and SRABC collectively addressed common challenges across the Deep South.

BESOL also added a grassroots component to the retirement security work. The Center for Community Change (CCC) was funded to inform low-income people and people of color about the impact of proposed Social Security reforms, build a national Social Security grassroots coalition, and create opportunities for them to educate policymakers about the priorities of their constituents. CCC worked with grassroots groups to conduct statewide efforts to support Social Security in Alabama, Florida, Illinois, Iowa, Louisiana, Maine, Michigan, Minnesota, Missouri, Montana, North Carolina, New Hampshire, Ohio, Pennsylvania, Virginia, and Washington. CCC also trained "Grassroots Ambassadors" to help lead the work. These ambassadors included people of color.

Consistent with the theory of change provision that those closest to the problem should be engaged in the development of the solutions, each coalition was required to build a grassroots constituency that was racially and ethnically representative of the communities that the coalition would serve. The leadership and the membership had to reflect the racial and ethnic makeup of the community.

\section{Developing a Policy Communications Infrastructure}

The mid-term assessment identified the need for a means by which grassroots, local, state, and national policy organizations could communicate on an ongoing and interactive basis. Such a policy communications infrastructure should allow people on the ground to have direct input into the work of educating local, state, and national policymakers so that newly developed policies would be relevant and effective for the people they are intended to serve.

PolicyLink, a research and advocacy organization, was asked to build a communications system that would create an accountable public policy process. Working with BESOL grantees, PolicyLink developed ACCESS (2012), an online system that housed information on all BESOL grantees, their publications, publications by the larger field, policy information, news events, and a calendar of events related to saving, asset building, and economic security. Communication across grantees and the field was facilitated through conference calls, webinars, blog posts, and twitter chats.

\section{The Braided Rug}

In launching the BESOL initiative, we held a convening of the grantees. At this meet, I told a story about the braided rugs that my grandmother used to make. She took strips of cloth from old garments and braided them together to form a long rope. My grandmother wound the rope in concentric circles until it formed a mat. Then she stitched the coils of rope together so that it would hold.

The braided rug was an analogy for BESOL. I likened the strips of cloth to the different approaches of the BESOL initiative-research, advocacy at all levels, and communication. The thread that ran throughout the rug and held all the strands of the rope together was the focus on closing the racial wealth gap.

The grantees were not expected to have expertise about the racial wealth gap. Instead, organizations with expertise on issues of race, ethnicity, and the racial wealth gap were provided with additional support to serve as resources for other BESOL grantees who requested their assistance.

For example, some of the grantees that identified closing the racial wealth gap as an objective were IABG, First Nations and its partners, and SRABC and each of its state coalitions. IABG engaged Thomas Shapiro and the Institute for Assets and Social Policy at Brandeis University to help develop a series of seminars on the racial wealth gap that were held in local communities across the state to raise awareness and increase participation in the coalition. The coalition also created a timeline for its website that provided information on each policy that impacted the racial wealth gap (IABG 2013).

First Nations and its partners engaged researchers from Howard University's Center on Race and Wealth to produce a study on subprime lending, homeownership, and foreclosures in Oklahoma's communities of color (Gobar 2011). The coalition released the report at an event for the public, media, and policymakers.

Researchers from Howard's Center on Race and Wealth also produced studies of the Great Recession and African American loss of land and homes in the SRABC states (Otabor and Nembhard 2012; Nembhard and Otabor 2012). In addition, Realize Consulting and SRABC engaged Insight and the Center for Family Policy and Practice to examine the impact of child support enforcement on lowincome men. These men typically had little or no means of paying economically crippling arrearages that accrued from penalties and fines-owed to the state, not the custodial parent and child(ren)—when the men were unable to 
keep up with child support orders (Boggess et al. 2014). ${ }^{2}$ Findings from these studies were shared at annual convenings held by SRABC that included a focus on the racial wealth gap. These convenings brought together grassroots constituents, academicians and policymakers from the southern states, other BESOL grantees, and national leaders and policymakers.

A focus on the racial wealth gap was not only incorporated into the work of the state coalitions, national organizations also worked on this issue. The Urban Institute conducted a number of studies that examined disparities in financial wealth between white families and families of color (McKernan et al. 2011, 2013, 2014, 2015). Most notably, Urban produced a whiteboard video The Racial Wealth Gap in America (2013) that clearly and coherently explained the racial wealth gap, the inequitable public policy that contributed to this gap, and solutions for addressing it. This video has received tens of thousands of views on YouTube.

\section{Expanding Research on the Racial Wealth Gap}

The BESOL initiative also supported the expansion of research on the racial wealth gap through primary data collection. One body of work was carried out by the IASP. In 2004, Shapiro published his book The Hidden Cost of Being African American that reported findings from interviews in 1998 with largely white and African American families in Boston, St. Louis, and Los Angeles. The book highlighted the existence of a wealth effect-the difference in mobility opportunities between people whose wealth is built from income alone versus those whose wealth is derived from income and family wealth. Shapiro found that strategically timed transfers of assets from individuals' families play a role in opening doors to social mobility. This research provided a snapshot of the families in terms of their existing asset sources and future aspirations. Ford provided funding for a second wave of interviews with these families to attain longitudinal data on the families' experiences with wealth accumulation.

IASP was subsequently funded to expand some of its prior research analyzing the national Panel Study on Income Dynamics which found that the racial wealth gap tripled between 1984 and 2009 (Shapiro et al. 2013). The extended research examined factors contributing to the

\footnotetext{
$\overline{2}$ Ronald Mincy, $\mathrm{PhD}$, also received support from Ford Foundation to conduct research on low-income, noncustodial parents. This work was published in his book Failing our Fathers: Confronting the Crisis of Economically Vulnerable Nonresident Fathers (2015). Mincy is the Maurice V. Russell Professor of Social Policy and Social Work Practice at the Columbia University School of Social Work and Director of the Center for Research on Fathers, Children and Family Well-Being.
}

change in wealth during that period. The combination of the qualitative analysis of the interviews and quantitative analysis of factors contributing to the racial wealth gap provided a more comprehensive understanding of the dynamics of asset accumulation and loss for families over time. This research resulted in a series of briefs called Leveraging Mobility (Thomas et al. 2013a, b, 2014a, b; Sullivan et al. 2015b).

And IASP received funding to collaborate with the public policy organization, Dēmos, in developing the racial wealth gap audit. The audit is a policy analysis tool to help assess the impact of policies and programs on the racial wealth gap. This tool can be used to analyze current or proposed policy and programs. (Sullivan et al. 2015a).

Ford also provided funding to the Duke University Research Network on Racial and Ethnic Inequality (Network) to measure the wealth gap by race, ethnicity, country of origin, and Native American tribal affiliation. Thus, for example, instead of only examining the extent of asset poverty among Latinos collectively, the research measured the wealth holdings of Cuban, Mexican, Puerto Rican, and Dominican ancestry groups separately.

The Network is comprised of multiracial and multiethnic researchers from across the country who designed the survey instrument, guided the data collection, are analyzing the data, and reporting the findings. Telephone surveys were initially conducted in Los Angeles, CA; Tulsa, OK; Washington, DC; and Miami, FL. The Federal Reserve Bank of Boston joined the research effort in collaboration with Ford so that Boston, MA, could be added to the study. And an in-person data collection effort is being carried out in Los Angeles.

The availability of more definitive research on the asset status of families should enhance the ability of scholars to determine the drivers of the racial wealth gap and increase the determination of policymakers to enact legislation that would reduce and eventually eliminate this disparity. A number of reports have been released from this study (Tippett et al. 2014; Muñoz et al. 2015; Hamilton et al. 2015; Nam et al. 2015) with more forthcoming.

\section{Effectively Communicating about the Racial Wealth Gap}

Race is one of the most difficult subjects for Americans to discuss. Drawing attention to racial disparities evokes the recognition of the long history of violence, terror, and injustice perpetuated against people of color in the USA. Rather than being receptive to information about racial disparities like the racial wealth gap, intended audiences can respond by shutting down or attempting to refute the information-no matter how rigorous the research is that produces the evidence. Such a reaction would defeat the 
purpose of the effort to marshal research, policy analysis, and advocacy on the issue. To address this dilemma, Ford supported work to develop a communications strategy for engaging different types of audiences about the racial wealth gap.

The Insight Center worked with consultants such as Anat Shenker-Osorio, a communications expert, to better understand how to write about and engage in discussions on the racial wealth gap. And in 2012, Insight designed the ECON convening to focus on better understanding implicit bias and how it can impact the interpretation of information that members attempt to convey in their work. Speakers included john powell, who had just completed his book Racing to Justice: Transforming Our Conceptions of Self and Other to Build an Inclusive Society (Powell 2012), and Isabel Wilkerson, author of The Warmth of Other Suns: The Epic Story of America's Great Migration (2010).

Ford also supported Opportunity Agenda, a social justice communications lab, to develop a communications strategy and set of messages on the racial wealth gap that would overcome the obstacles of addressing race and ethnicity. Opportunity agenda gleaned information from its Opportunity Survey. This was a national poll of the American population that oversampled low-income Americans and people of color, and conducted public opinion meta-analysis, media analysis, a social media scan, and an assessment of research on implicit bias. Based on this work, Opportunity agenda created tailored materials for racial wealth gap grantees and communication strategy advice for allies. In 2014, Opportunity Agenda gave a presentation at the SRABC annual convening and conducted workshops for attendees on how to effectively communicate messages about the racial wealth gap. Opportunity Agenda was joined by Anat Shenker-Osorio in conducting workshops for ECON members who attended the 2015 Color of Wealth Summit organized by CGPS and Insight on Capitol Hill.

\section{Visibility}

Not only was it important for the grantees in BESOL to communicate with each other, it also was important for the Ford Foundation to be aware of the work being conducted by these grantees. Both of these objectives were addressed through annual convenings of the grantees at Ford. The first day of convenings was held just for state and regional coalitions and the organizations that served as resources for their work. They shared strategies for coalition building and solving challenges. The second and third days of the convenings brought all grantees together. Through panel presentations and discussions, they learned about each other's work and where there might be opportunities for collaboration.
In addition, the leadership-president, vice president, and directors - of the Foundation, as well as other program officers, participated in the annual convenings. They provided remarks and heard directly from the grantees about the progress and challenges in their work, including their work on the racial wealth gap. These annual meetings allowed people to build connections and made real the work that was described in annual reports, research studies, and publications. The convenings helped keep the work visible.

\section{From Tuskegee to Capitol Hill}

In the spring of 2015, the Center for Global Policy Solutions and Insight held the Color of Wealth Summit on Capitol Hill with a full auditorium. Leadership of Congressional caucuses provided keynote remarks, journalists from the Washington Post and PBS News Hour moderated panels and nationally known researchers, policy advocates, and academics-including BESOL grantees-spoke on panels. The audience came from all across the country to learn more about the issue of the racial wealth gap. Members of ECON, who now number over 180, participated as panelists or observed from the audience. And, as mentioned above, ECON members spent an additional day immersed in workshops sharpening their skills at researching and communicating about the racial wealth gap. Since then, the ECON Beltway Committee-originally formed in 2009-has met monthly to fine tune the ECON policy agenda and educate members of Congress about it. Members of ECON appear regularly in Congressional hearings and on news talk show, their research articles appear in scholarly journals, and their editorials and blogs are frequently carried by national and local media. BESOL grantees in general and ECON members in particular have brought the racial wealth gap to the attention of the American public, media, and policymakers.

\section{Final Thoughts}

Over the last few years, there has been a growing number of protests across the country by communities of color and their allies. While the flash point has often been the violent or deadly use of force by police or members of the public against African Americans and other people of color, increasingly there has been deeper investigation of the factors contributing to these flashpoints and the protests. The racial wealth gap and the drivers of this economic disparity are receiving growing attention. The body of work that has been generated on the racial wealth gap by the grantees of the saving and asset building portfolio and the BESOL initiative offers an unmatched resource for policymakers, agency administrators, nonprofit 
organizations, the media, and the general public to study and find solutions.

Open Access This article is distributed under the terms of the Creative Commons Attribution 4.0 International License (http://crea tivecommons.org/licenses/by/4.0/), which permits unrestricted use, distribution, and reproduction in any medium, provided you give appropriate credit to the original author(s) and the source, provide a link to the Creative Commons license, and indicate if changes were made.

\section{References}

Beverly, S. G., Clancy, M. M., \& Sherraden, M. (2015). The early positive impacts of child development accounts. St. Louis, MO: Center for Social Development.

Boggess, J., Price, A., \& Rodriguez, N. (2014). What we want to give our kids: How child support debt can diminish wealth-building opportunities for struggling black fathers and their families. Madison, WI and Oakland, CA: Center for Family Policy and Practice and Insight Center for Community Economic Development.

Gobar, A. M. (2011). Oklahoma mortgage lending patterns: An analysis of patterns of subprime lending and homeownership and foreclosures among people of color in Tulsa and Oklahoma City MSAs. Washington, DC: Howard University.

Hamilton, D., Darity, W., Price, A., Sridharan, V., \& Tippett, R. (2015). Umbrellas don't make it rain: Why studying and working hard isn't enough for Black Americans. Oakland, CA: Insight Center for Community Economic Development.

Lui, Meihzu. (2009). Laying the foundation for national prosperity: The imperative of closing the racial wealth gap. Oakland, CA: Insight Center for Community and Economic Development.

Marks, E., Engelhardt, G., Rhodes, B., \& Wallace, I. (2014). SEED for Oklahoma kids: The impact evaluation. Research Triangle Park, NC: RTI International.

McKernan, S., Ratcliffe, C., Simms, M., \& Zhang, S. (2011). Private transfers, race, and wealth. Washington, DC: Urban Institute.

McKernan, S., Ratcliffe, C., Simms, M., \& Zhang, S. (2014). Do racial disparities in private transfers help explain the racial wealth gap? New evidence from longitudinal data. Washington, DC: Urban Institute.

McKernan, S., Ratcliffe, C., Steuerle, E. C., Kalish, E., \& Quackenbush, C. (2015). Nine charts about wealth inequality in America. http://datatools.urban.org/Features/wealth-inequalitycharts/.

McKernan, S., Ratcliffe, C., Steuerle, E. C., \& Zhang, S. (2013). Less than equal: Racial disparities in wealth accumulation. Washington, DC: Urban Institute.

Mills, G., Patterson, R., Orr, L., \& DeMarco, D. (2004). Evaluation of the American dream demonstration: Final evaluation report. Cambridge, MA: Abt Associates.

Mincy, R. B., Jethwani, M., \& Klempin, S. (2015). Failing our fathers: Confronting the crisis of economically vulnerable nonresident fathers. Oxford: University Press.

Muñoz, A., Kim, M., Chang, M., Jackson, R. O., Hamilton, D., \& Darity, W. (2015). The color of wealth in Boston. Boston, MA: Federal Reserve Bank of Boston.

Nam, Y., Hamilton, D., Darity, W., \& Price, A. (2015). Bootstraps are for black kids: Race, wealth, and the impact of intergenerational transfers on adult outcomes. Oakland, CA: Insight Center for Community Economic Development.

Nembhard, J. G., \& Otabor, C. (2012). The Great Recession and land and housing loss in African American communities: Case studies from Alabama, Florida, Louisiana, and Mississippi Part 2: Heir property. Washington, DC: Howard University.

Oliver, M. L., \& Shapiro, T. M. (1997). Black wealth/White wealth: A new perspective on racial inequality. New York and London: Routledge.

Otabor, C., \& Nembhard, J. G. (2012). The great recession and land and housing loss in African American communities: Case studies from Alabama, Florida, Louisiana, and Mississippi Part 1: Home foreclosures. Washington, DC: Howard University.

PolicyLink. (2012). Access to financial security. http://www.policy link.org/focus-areas/access-to-financial-security

Powell, J. A. (2012). Racing to justice: Transforming our conceptions of self and other to build an inclusive society. Bloomington and Indianapolis, IN: Indiana University Press.

Rawlings, L., \& Williams, A. (2012). Design, outcomes, and lessons learned from the Urban Institute Academy for Public Policy Analysis and Research pilot program. Washington, DC: Urban Institute.

Rockeymoore, M. M., \& Lui, M. (2011). Plan for a new future: The impact of Social Security reform on people of color. Washington, DC: Commission to Modernize Social Security.

Schreiner, R., Clancy, M., \& Sherraden, M. (2002). Saving performance in the American Dream Demonstration: A national demonstration of individual development accounts. St. Louis, MO: Center for Social Development.

Shapiro, T., Meschede, T., \& Osoro, S. (2013). The roots of the widening racial wealth gap: Explaining the Black-White economic divide. Waltham, MA: Institute on Assets and Social Policy.

Sherraden, M. (1991). Asset and the poor: A new American welfare policy. Armonk, NY: M.E. Sharpe Inc.

Sullivan, L., Meschede, T., Dietrich, L., Shapiro, T., Traub, A., Ruetschlin, C., \& Draut, T. (2015a). The racial wealth gap: Why policy matters. New York: Dēmos.

Sullivan, L., Meschede, T., Mann, A., Ramirez-Kuykendall, S., \& Shapiro, T. (2015). Navigating an unclear path: Preparing for retirement in the 21 st century. Leveraging mobility series. Waltham, MA: Institute on Assets and Social Policy.

Thomas, H., Boguslaw, J., Chaganti, S., Atkinson, A., \& Shapiro, T. (2013a). Employment capital: How work builds and protects family wealth and security. Leveraging mobility series. Waltham, MA: Institute on Assets and Social Policy.

Thomas, H., Boguslaw, J., Mann, A., \& Shapiro, T. (2013b). Leveraging mobility: Building wealth, security and opportunity for family well-being. Leveraging mobility series. Waltham, MA: Institute on Assets and Social Policy.

Thomas, H., Meschede, T., Mann, A., Boguslaw, J., \& Shapiro, T. (2014a). "The web of wealth: Resiliency and opportunity or driver of inequality?" Leveraging mobility series. Waltham, MA: Institute on Assets and Social Policy

Thomas, H., Meschede, T., Mann, A., Stagg, A., \& Shapiro, T. (2014b). "Location, location, location: The role neighborhoods play in family wealth and well-being." Leveraging mobility series. Waltham, MA: Institute on Assets and Social Policy.

Tippett, R., Jones-DeWeever, A., Rockeymoore, M., Hamilton, D., \& Darity, W. (2014). Beyond broke: Why closing the racial wealth gap is a priority for national economic security. Washington, DC: Center for Global Policy Solutions.

Urban Institute (2013). The racial wealth gap in America. http:// www.urban.org/urban-wire/racial-wealth-gap-was-wide-1963and-it-remains-large-today.

Washington, O., \& Koen, D. (2007). A path to the future: Closing the racial wealth gap. New York: Washington Koen Productions.

Wilkerson, I. (2010). The warmth of other suns: The epic story of America's great migration. New York: Vintage Books. 